\title{
Slope design at Cuajone Pit, Peru
}

\author{
E. Hormazabal SRK Consulting (Chile) S.A., Chile \\ R. Veramendi Southern Peru Copper Corporation, Peru \\ J. Barrios Southern Peru Copper Corporation, Peru \\ G. Zuñiga SRK Consulting (Chile) S.A., Chile \\ F. Gonzalez SRK Consulting (Chile) S.A., Chile
}

\begin{abstract}
The Cuajone porphyry copper deposit is located on the western slopes of Cordillera Occidental, the southern Andes of Peru. The current pit measures about $2.5 \mathrm{~km}$ east-west, $3.0 \mathrm{~km}$ north-south, and at the end of 2012, had a maximum depth of $950 \mathrm{~m}$. Mining by open pit methods commenced in 1976 and has continued since that time. Ore production is $80 \mathrm{ktpd}$.
\end{abstract}

As part of the slope design program and slope optimisation, the past and present performance of the pit slopes was evaluated to provide information on the potential behaviour of future pit expansion. A geomechanical assessment is being carried out to evaluate the stability of the walls of the next expansion. To evaluate the stability of the open pit, a series of geotechnical studies have been performed. These studies involve, among others, slope stability analyses based on limit equilibrium methods and finite element numerical models. In addition, a detailed back-analysis of a five million ton failure (DSE42) was performed to calibrate rock mass properties and to understand slope behaviour in poor rock mass quality.

This paper describes the back-analysis of the DSE42 failure and the slope design process for the current pit and next pushback.

\section{$1 \quad$ Introduction}

SPCC is currently evaluating at a feasibility engineering level the LOM for the next 15 years of mining of the Cuajone pit. The Cuajone porphyry copper deposit is located on the western slopes of Cordillera Occidental, the southern Andes of Peru (see Figure 1).

At Cuajone Mine, the experience of past failures provides an excellent basis for design of the proposed designs. The geological and structural information gathered by the mine staff also provides good data for the confidence in design. Since there is a measure of apprehension of successful slope design implementation from past failures, back-analyses of these failures are essential to provide the level of confidence in parameters that is required to proceed with the next pushback.

\section{$2 \quad$ Engineering geology}

\section{$2.1 \quad$ Mine geology}

The Cuajone district exposes several thousand metres of volcanic rocks assigned by Bellido and Landa (1965) and Bellido (1979) to the Paraleque Volcanics and Quellaveco Formation of the Upper Cretaceous to Paleocene Toquepala Group. The stratigraphy will be divided into three broad categories: pre-mineralisation rocks; intrusive rocks; and post-mineralisation rocks. 


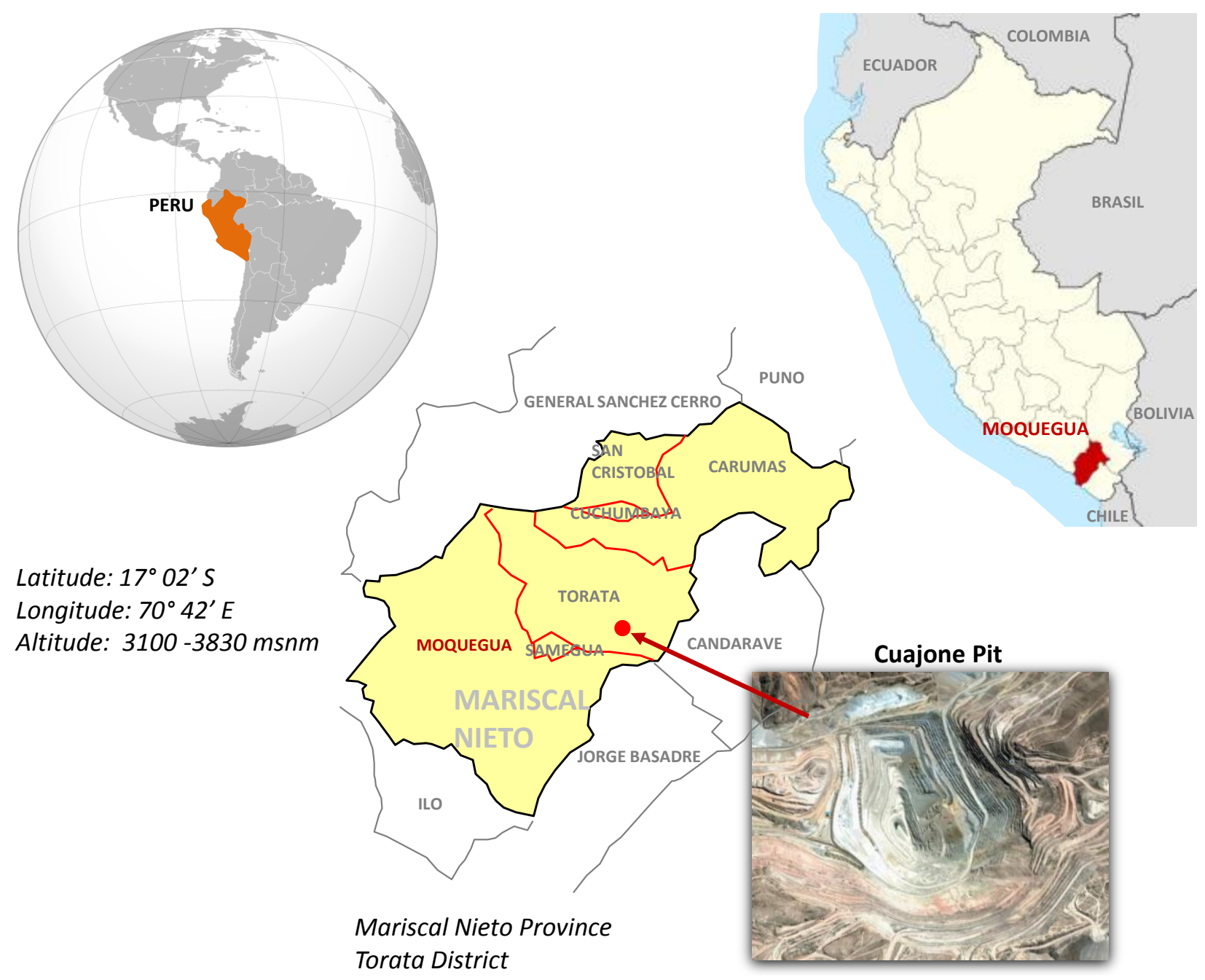

Figure 1 Location of Cuajone Mine

\subsubsection{Pre-mineralisation volcanic rocks}

The pre-mineralisation rocks of the area are Basaltic Andesite and Rhyolite Porphyry. They are considered to be part of the Toquepala Group and Upper Cretaceous to Lower Tertiary age. Basaltic Andesite (BA): is the oldest rock unit and constitutes the basement rocks in the area. It is greenish grey in colour, fine grained, and commonly porphyritic with phenocrysts of plagioclase. Rhyolite Porphyry (RP): the unit is a volcanic flow with phenocrysts of generally sub-rounded quartz grains of up to $2 \mathrm{~mm}$ in diameter in an aphanitic groundmass. This unit overlies the andesitic rocks. The rock is dense and hard; colour is light grey to greyish white.

\subsubsection{Intrusive rocks}

Diorite (DI): is grey to greenish grey in colour, medium to coarse-grained, and occasionally porphyritic. The diorite underlies the BA. Latite Porphyry (LP): the LP intrusive body forms the core of the Cuajone Mine. It is elongated in a northwest-southeast direction; it is $2.5 \mathrm{~km}$ long and approximately $0.7 \mathrm{~km}$ wide. The rock is usually highly altered; phenocrysts of sub-rounded quartz grains (up to $4 \mathrm{~mm}$ in diameter) and rectangular feldspars are present in a cryptocrystalline matrix. Breccias (BX, BXmg, BxM): the emplacement of the intrusive brecciated the surrounding rock. The resulting breccias consist of rounded to sub-angular fragments of primarily latites and andesites in a latite porphyry matrix. Rhyolite Conglomerate (CR): overlying the mineralised rocks, and underlying the post mineralisation cover rocks, are poorly consolidated channel fills. They outcrop in the eastern limits of the current pit, in east-west trending paleochannels. They consist of sub-rounded to sub-angular clasts of predominant RP in a loamy-sandy matrix. 


\subsubsection{Post-mineralisation cover rocks}

Thick and extensive post-mineralisation cover rocks are present in the mine area. They are, starting from the oldest: Huaylillas, Chuntacala, and Post-Chuntacala Formations, all of which are represented by volcanic rock sequences.

\subsubsection{Huaylillas formation}

Vitrophyre/salmon tuff (VT/TS): this unit is uniformly present at the base of Huaylillas flow rocks and disconformably overlies the pre-mineralisation volcanic and intrusive rocks. TS, the lower part of the unit, consists of a pink-orange ashfall tuff that changes in colour to white towards the top. Thickness is up to $16 \mathrm{~m}$. Sanidine, phlogopite, and chlorite are the dominant coarse minerals. Overlying the TS is glassy VT, black to brownish black in colour and with prominent conchoidal fractures and sanidine phenocrysts. Thickness is variable, with a maximum of $20 \mathrm{~m}$. Trachytes (TR): this unit is greater than $100 \mathrm{~m}$ thick and is very prominent on the south walls of the mine. It is thick bedded, characterised by flow banding and vesicles of varying diameter. The colour is rosy brown with violet hues. Subhorizontal and vertical joints/fractures are prominent; these reflect a crudely formed columnar jointing. Basal Conglomerate (CB): overlying the Huaylillas Formation, and underlying the Chuntacala Formation, are poorly consolidated paleosols and channel fills. These sediments are up to $32 \mathrm{~m}$ thick and are the thickest in east-west trending channels. They consist of sub-angular to rounded fragments of predominantly andesitic rocks, with smaller amounts of rhyolite, trachyte, and tuffs in a sandy-loamy groundmass. CB is believed to be a high permeability zone with significant influence on the water flow in the area.

\subsubsection{Chuntacala formation}

Crystal tuff (TC): the TC unit is up to $120 \mathrm{~m}$ thick, with a basal whitish grey tuff (approximately $5 \mathrm{~m}$ thick) overlain by clear brown tuff. The basal tuff is soft ashfall; the brown tuff has a medium to coarse-grained groundmass with porphyritic texture and phenocrysts of sanidine and mica. The unit has very prominent, crudely vertical columnar jointing; the joints are often filled with pyrolusite and clay. Lower tuff (TI): TI overlies the TC; the disconformable contact can be subdued and may appear to be gradational. The tuff is white to yellowish in colour, generally soft, with an aphanitic groundmass, and is weakly porphyritic. In the north side of the pit, the unit is $90 \mathrm{~m}$ thick. Lower Agglomerate (Al): this unit is paleovalley fill and unconformably overlies TI and TC. It is a dark brown agglomeratic flow, mostly composed of sub-rounded clasts of andesite, up to $40 \mathrm{~cm}$ in diameter, in a consolidated tuffaceous groundmass. The maximum thickness recorded is $90 \mathrm{~m}$ along the central axis of the paleovalley. Upper tuff (TS): the contact between the TS and the underlying $\mathrm{Al}$ is generally conformable. The unit is rosy white in colour, with porphyritic texture, and a fine groundmass. The maximum thickness recorded is $65 \mathrm{~m}$. Andesite Porphyry (PA): PA and the overlying AS are separated by an erosional discordant contact. The unit is an andesitic flow, porphyritic in texture, and grey to black colour. Upper Agglomerate (AS): this unit overlies the TS and is the upper unit of the Chuntacala Formation. The groundmass is tuffaceous with clasts of mostly andesites and tuffs. The unit is up to $50 \mathrm{~m}$ thick.

\subsubsection{Alteration types}

The alteration types mapped in the Cuajone Mine are the results of supergene and hydrothermal processes. The four mappable supergene zones, starting from the top, are: a leached cap, approximately $90 \mathrm{~m}$ thick; an oxide zone, approximately $45 \mathrm{~m}$ thick; a supergene-enriched zone, approximately $30 \mathrm{~m}$ thick; and a transitional zone, approximately $180 \mathrm{~m}$ thick. The argillic alteration mapped in the mine coincides with the transitional zone.

The hydrothermal alteration patterns mapped in the mine are quite typical of porphyry-copper systems. Phyllic alteration is the dominant type within the Cuajone orebody. It is an intense, pervasive alteration assemblage characterised by $40-50 \%$ fine-grained sericite, with the remainder being secondary quartz. The outer fringes of the deposit are characterised by propyllitic alteration. In the propylitic zone there is a 
dramatic decrease in the quartz-sericite content; mafic minerals are replaced by chlorite and epidote. The rock is hard and competent.

The mineral zones at Cuajone Mine have a controlling influence on its copper grades and geotechnical characteristics. From top to bottom in the profile the major mineral zones are: post mineral cover, leaching cap, oxide, secondary enrichment, transitional and primary zone.

\subsection{Structural geology}

According to the geotechnical information provided from surface mapping and logging of several campaigns in the past in Cuajone pit, seven structural domains have been defined. Although the regional structures played a major role in the localisation of the Cuajone deposit, the geological setting and structure around the LP emplacement are unique. Most important structures are steep and therefore project to the surface. The major structural features (fault zones) of the Cuajone Mine are: Viña Blanca, Botiflaca, Cuajone, Paleochuntacala and South Major. As part of the slope design process, structural domains were defined for the current pit and areas for the pushback. These domains are areas in which the general characteristics of the structural fabric are expected to be uniform: the boundaries of such domains are typically major faults or lithological features (SRK Consulting, 2012). Figure 2 shows the location of structural domains, designated $A$ to $G$, in the current Cuajone pit.

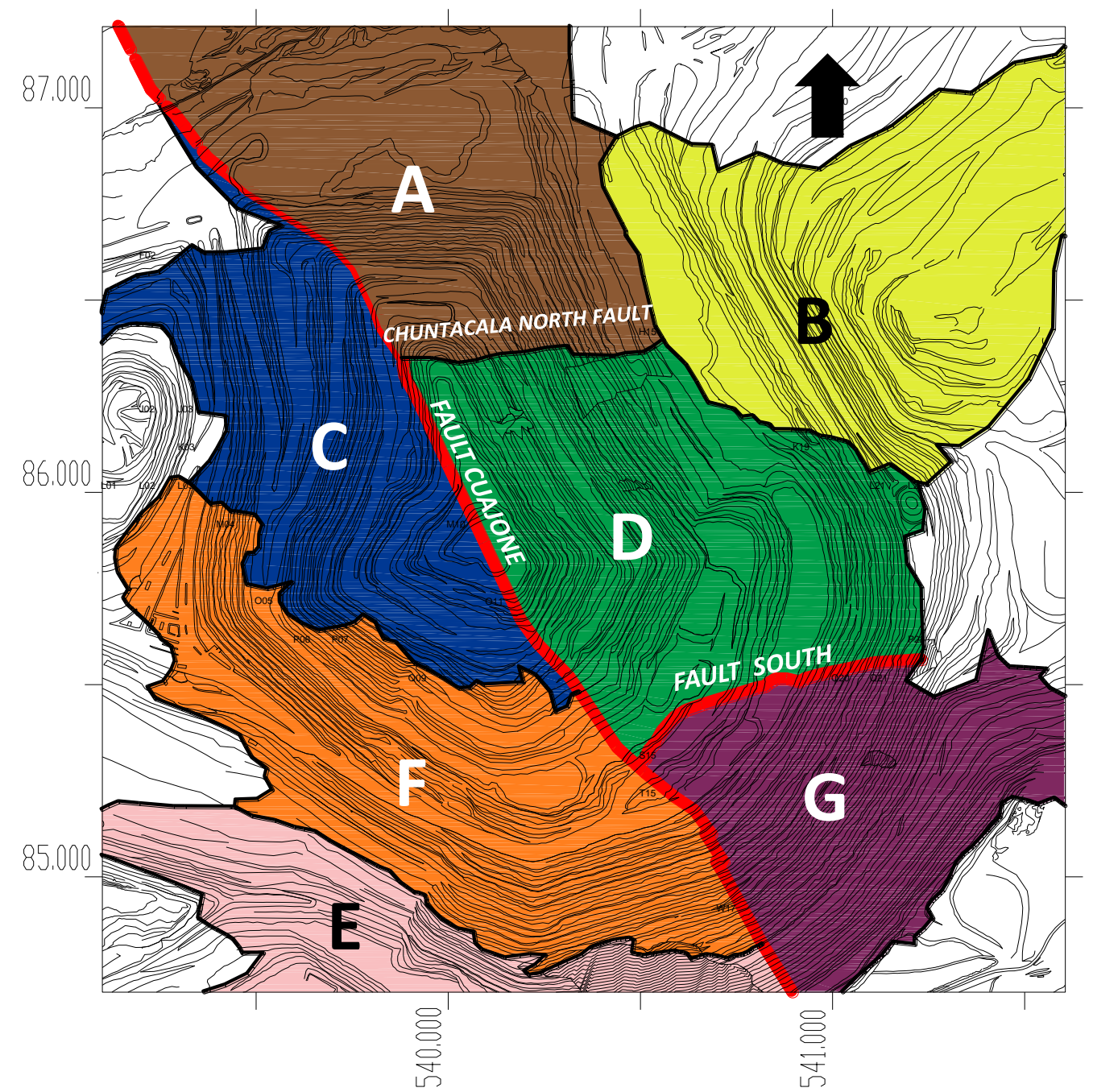

Figure 2 Structural domains at Cuajone pit. Blue lines are the major faults that limit some structural domains 


\subsection{Geotechnical units and rock mass characterisation}

The geotechnical units were defined by the superposition of lithology, alteration and mineral zone. The main geotechnical units, UG 1 to UG 15 present at Cuajone pit are shown in Table 1 . The last column shows the relative importance by mined volume corresponding to the LOM pit. The geotechnical characterisation is based on geological-geotechnical borehole logging and surface mapping. From previous drill core campaigns, the geotechnical quality of the rock mass was rated using the rock mass rating $\left(\mathrm{RMR}_{89}\right)$ defined by Bieniawski (1989). With this information a geotechnical block model was developed, which includes geotechnical parameters such as: geotechnical unit, $\mathrm{RMR}_{89}$ and GSI (Hoek, 1994). This model was based on geological, structural, mineral zones and alteration models. Figure 3, shows the distribution of the different geotechnical units from the geotechnical block model in the current pit.

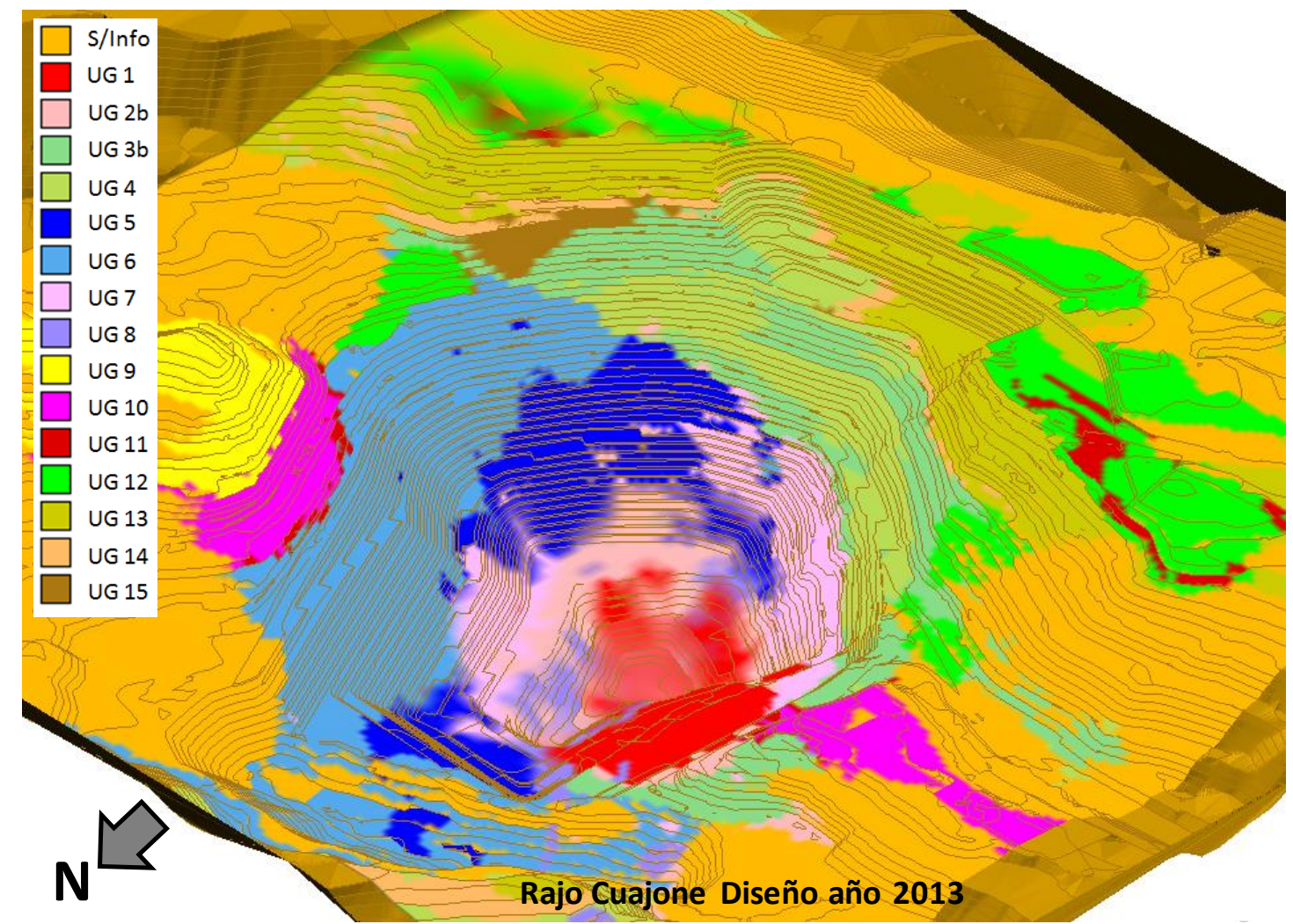

Figure 3 Main geotechnical units at Cuajone Mine, refer to Table 1 for unit descriptions

The rock mass properties for the geotechnical units were evaluated with the Hoek-Brown criterion (Hoek et al., 2002), using the results of laboratory testing (uniaxial compressive strength, triaxial and Brazilian tests). Table 2 summarises the geotechnical properties of the rock mass.

A hydrogeological conceptual model was developed by Water Management Services (WMC, 1999), considering outcrops, borehole loggings and all the available hydrogeological information on the site, pumping tests, packer tests and open standpipe piezometers. This model is currently in the process of being updated. This information was used in the limit equilibrium stability analyses and numerical model simulations. 
Table 1 Geotechnical units at Cuajone

\begin{tabular}{|c|c|c|c|c|c|c|c|c|c|c|c|c|c|c|c|c|c|c|}
\hline Code & Lithology & & & Alte & erati & ion & & & & Mine & eral Z & Zone & & & Geotechni & ical Units & & $\begin{array}{c}\text { Lom } 15 \\
\text { Years }\end{array}$ \\
\hline LP & Porphyritic latite & & & & & & & & & & & & & & & & & \\
\hline $\begin{array}{l}\text { BLP } \\
\text { DK }\end{array}$ & $\begin{array}{l}\text { Sterile porphyritic } \\
\text { latite } \\
\text { Porphyritic latite } \\
\text { dike }\end{array}$ & & & & & & & & & & & & & Latite & $\begin{array}{l}\text { Phyllic- } \\
\text { propylitic }\end{array}$ & Primary & UG 1 & $12.6 \%$ \\
\hline LP3 & $\begin{array}{l}\text { Porphyritic latite } \\
\text { LP3 }\end{array}$ & & & & & & & & & & & & & & Phyllic & $\begin{array}{l}\text { Secondary/ } \\
\text { leached }\end{array}$ & UG $2 a$ & $1.0 \%$ \\
\hline $\mathrm{RP}$ & Porphyritic rhyolite & & & & & & & & & & & & & & & Primary & UG $2 b$ & $5.6 \%$ \\
\hline BA & Basaltic andesite & & & & & & & & & & & & & & & Secondary/ & UG 3a & $4.9 \%$ \\
\hline IA & Intrusive andesite & & & & & & & & & & & & & & & leached & UG $3 b$ & $4.9 \%$ \\
\hline $\begin{array}{l}\text { DI } \\
\text { DO }\end{array}$ & $\begin{array}{l}\text { Diorite } \\
\text { Dolerita }\end{array}$ & & & & & & & & & & & & & Rhyolite & Argillic & Primary & UG 4 & $2.6 \%$ \\
\hline BXE & Sterile breccia & & & & & & & & & & & & & & & & & \\
\hline BX-IA & $\begin{array}{l}\text { Breccia of intrusive } \\
\text { andesite }\end{array}$ & & & & & & & & & & & & & Basaltic & Pronvlitic & Primary & UG 5 & $17.5 \%$ \\
\hline BX-BLP & Breccia of BLP & & & & & & & & & & & & & andesite & PropyIItic & & & \\
\hline BX-RP & $\begin{array}{l}\text { Breccia of } \\
\text { porphyritic phyolite }\end{array}$ & $\stackrel{\oplus}{ \pm}$ & & & $\stackrel{\sqrt[\pi]{=}}{=}$ & $\widehat{\pi}$ & : & & & & & & & & & $\begin{array}{l}\text { secondary/ } \\
\text { leached }\end{array}$ & UG 6 & $5.7 \%$ \\
\hline $\begin{array}{l}\text { BX-BA } \\
\text { BXLPM }\end{array}$ & $\begin{array}{l}\text { Breccia of basaltic } \\
\text { andesite } \\
\text { Breccia of } \\
\text { porphyritic latite }\end{array}$ & 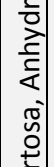 & . & 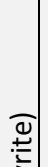 & 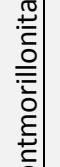 & 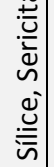 & $\mid \begin{array}{c}0 \\
0 \\
0 \\
0 \\
0 \\
0 \\
0 \\
0 \\
0 \\
0\end{array}$ & 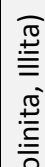 & $\widehat{0}$ & & & & & $\begin{array}{l}\text { Andesite } \\
\text { intrusive }\end{array}$ & Phyllic & Primary & UG 7 & $10.2 \%$ \\
\hline $\begin{array}{l}\text { BXMG } \\
\text { PX }\end{array}$ & $\begin{array}{l}\text { Marginal breccia } \\
\text { Pebble brecha }\end{array}$ & ठ̀ & 음 & 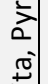 & $\sum_{0}^{0}$ & 竎 & $\begin{array}{c}. \bar{v} \\
\overline{\bar{n}} \\
u\end{array}$ & 范 & : & & & & & $\begin{array}{l}\text { Breccia of } \\
\text { andesite }\end{array}$ & Phyllic & Primary & UG 8 & $3.2 \%$ \\
\hline BXT & Turmaline breccia & $\frac{\bar{n}}{\bar{n}}$ & : & 苞 & 营 & $\underset{\sigma}{5}$ & : & $\frac{\underline{\underline{T}}}{. \underline{\underline{u}}}$ & o. & $\tilde{4}$ & ㅇ & $\left|\begin{array}{l}\pi \\
0 \\
0\end{array}\right|$ & $\geq$ & \multirow{2}{*}{\multicolumn{3}{|c|}{ Lower tuff }} & & \\
\hline PA & $\begin{array}{l}\text { Porphyritic } \\
\text { andesite } \\
\text { Upper agglomerate }\end{array}$ & 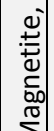 & 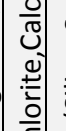 & 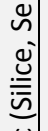 & 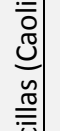 & \begin{tabular}{l|}
$\sum_{0}^{\infty}$ \\
$\stackrel{0}{ \pm 0}$ \\
.0 \\
.0
\end{tabular} & $\mid$ & 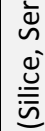 & 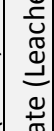 & . & 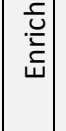 & 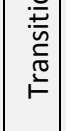 & 章 & & & & UG 9 & $3.0 \%$ \\
\hline Al & Lower agglomerate & $\sum$ & 矛: & 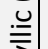 & 哥 & $\stackrel{\varrho}{u}$ & $\frac{0}{\mathrm{C}}$ &.$\underline{\underline{u}}$ & $\overbrace{\frac{\pi}{x}}^{2}$ & & & & & \multirow{3}{*}{\multicolumn{3}{|c|}{ Crystalline tuff }} & & \\
\hline TS & Upper tuff & $\stackrel{\oplus}{ \pm}$ & .0 & $\overrightarrow{\frac{a}{a}}$ & .0 & $\begin{array}{l}\bar{n} \\
\bar{v}\end{array}$ & . & $\overline{\overline{\bar{\sigma}}}$ & .X. & & & & & & & & UG 10 & $6.1 \%$ \\
\hline $\mathrm{TI}$ & Lower tuff & .0 & 빛 & & 言帝 & 菅 & 芜 & 市 & & & & & & & & & & \\
\hline TC & Crystalline tuff & $\stackrel{\underline{u}}{.0}$ & 은 & & $\begin{array}{l}\bar{\pi} \\
0 \\
0\end{array} \mid$ & 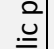 & 잉 & 产 & & & & & & \multirow{3}{*}{\multicolumn{3}{|c|}{ Basal conglomerate }} & & \\
\hline TBM & Micacea tuff & $\overline{\breve{s}}$ & & & ปั. & 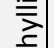 & 흔 & $\frac{5}{2}$ & & & & & & & & & UG 11 & $0.9 \%$ \\
\hline $\mathrm{CB}$ & Basal conglomerate & 苛 & & & 这 & $\frac{1}{a}$ & 言 & & & & & & & & & & & \\
\hline TBC & Café tuff & & & & 气ำ & & $\frac{c}{2}$ & & & & & & & \multirow{3}{*}{\multicolumn{3}{|c|}{ Trachytic tuff }} & & \\
\hline AT & $\begin{array}{l}\text { Aglomerado } \\
\text { tobaceo }\end{array}$ & & & & & & & & & & & & & & & & UG 12 & $2.8 \%$ \\
\hline AG & Gray agglomerate & & & & & & & & & & & & & & & & & \\
\hline TB & White tuff & & & & & & & & & & & & & \multirow{3}{*}{\multicolumn{3}{|c|}{ Trachyte }} & & \\
\hline TBTR & Trachytic tuff & & & & & & & & & & & & & & & & UG 13 & $21.2 \%$ \\
\hline $\mathrm{CA} / \mathrm{CV}$ & $\begin{array}{l}\text { Yellow/green } \\
\text { conglomerate }\end{array}$ & & & & & & & & & & & & & & & & & \\
\hline AGTR & $\begin{array}{l}\text { Trachytic } \\
\text { agglomerate }\end{array}$ & & & & & & & & & & & & & \multirow{3}{*}{\multicolumn{3}{|c|}{ Salmon tuff }} & & \\
\hline CTR & $\begin{array}{l}\text { Trachytic } \\
\text { conglomerate }\end{array}$ & & & & & & & & & & & & & & & & UG 14 & $1.3 \%$ \\
\hline TR & Trachyte & & & & & & & & & & & & & & & & & \\
\hline $\begin{array}{l}\text { TSA } \\
\text { VT }\end{array}$ & $\begin{array}{l}\text { Salmon tuff } \\
\text { Vitrofiro }\end{array}$ & & & & & & & & & & & & & \multirow{2}{*}{\multicolumn{3}{|c|}{ Rhyolitic conglomerate }} & & \\
\hline $\mathrm{CR}$ & $\begin{array}{l}\text { Rhyolitic } \\
\text { conglomerate }\end{array}$ & & & & & & & & & & & & & & & & UG 15 & $1.3 \%$ \\
\hline
\end{tabular}


Table 2 Geotechnical properties of the rock mass

\begin{tabular}{|c|c|c|c|c|c|c|}
\hline \multirow[b]{2}{*}{ Geotechnical Units } & \multicolumn{6}{|c|}{ Rock Mass Properties } \\
\hline & $\begin{array}{c}\gamma \\
\left(t / m^{3}\right)\end{array}$ & GSI (average) & $\begin{array}{c}E_{\mathrm{RM}} \\
(\mathrm{GPa})\end{array}$ & $v$ & $\begin{array}{c}c \\
(\mathrm{kPa})\end{array}$ & $\begin{array}{c}\phi \\
\left({ }^{\circ}\right)\end{array}$ \\
\hline UG 01 & 2.63 & 52 & 5.4 & 0.24 & 2,177 & 39 \\
\hline UG 02a & 2.60 & 30 & 0.6 & 0.29 & 987 & 25 \\
\hline UG 02b & 2.63 & 52 & 5.4 & 0.24 & 2,177 & 39 \\
\hline UG 03a & 2.62 & 25 & 0.9 & 0.3 & 653 & 22 \\
\hline UG $3 b$ & 2.62 & 40 & 1.7 & 0.27 & 1,032 & 25 \\
\hline UG 04 & 2.69 & 55 & 11.1 & 0.23 & 2,031 & 36 \\
\hline UG 05 & 2.78 & 50 & 6.9 & 0.25 & 2,327 & 39 \\
\hline UG 06 & 2.74 & 50 & 3.6 & 0.25 & 1,433 & 29 \\
\hline UG 07 & 2.70 & 45 & 2.6 & 0.26 & 1,465 & 30 \\
\hline UG 08 & 2.70 & 45 & 2.6 & 0.26 & 1,465 & 30 \\
\hline UG 09 & 2.33 & 49 & 0.3 & 0.25 & 653 & 19 \\
\hline UG 10 & 2.33 & 53 & 3.0 & 0.24 & 2,187 & 43 \\
\hline UG 11 & 2.33 & 49 & 0.3 & 0.25 & 653 & 19 \\
\hline UG 13 & 2.36 & 48 & 5.5 & 0.25 & 2,341 & 43 \\
\hline UG 14 & & & & & 100 & 25 \\
\hline UG 15 & & & & & 100 & 30 \\
\hline & & & & & & \\
\hline $\begin{array}{l}\text { Unit weight } \\
\text { Geological Strength Index (Ho } \\
\text { Rock Mass Young's modulus ( } \\
\text { Poisson Ratio } \\
\text { Rock mass cohesion } \\
\text { Friction angle }\end{array}$ & $\begin{array}{l}\text { 1994) } \\
\text { k and Died }\end{array}$ & richs, 2005) & & & & \\
\hline
\end{tabular}

\section{$3 \quad$ Slope design}

Failures at Cuajone display a number of classical failure mechanisms i.e. large scale wedge failures and circular arc failures in highly altered soft rock. In mid February 1999 a failure of approximately 12 million tonnes occurred (see Figure 5). The failure occurred through BA with the toe of the failure thought to lie within the upper portion of the LP, or the base of the BA (Golder Associates et al., 2000). The failure in Figure 4 is typical of a soft rock circular arc failure mode, with shear strength controlled by cohesion rather than friction. There is also strong evidence that groundwater pressures played a significant role in the failure. Immediately before the failure, there had been a period of heavy rainfall.

With the abundance of experience of the different failure modes available at Cuajone, the design of the future planned cutback can be carried out with considerable confidence. Back-analyses play an important part in the confidence of design. This is further backed up by the good data generated following the mapping of structures undertaken since the failures. The failure modes are not over complicated and can be reasonably simulated by known analytical models. 
Using the data obtained from the back-analyses, the following design processes are envisaged for the south wall pushback:

- Kinematic analyses on structural data for bench berm design and inter-ramp slopes.

- Slope stability analyses using limit equilibrium method.

- Numerical modelling of the overall slope design and within critical sectors.

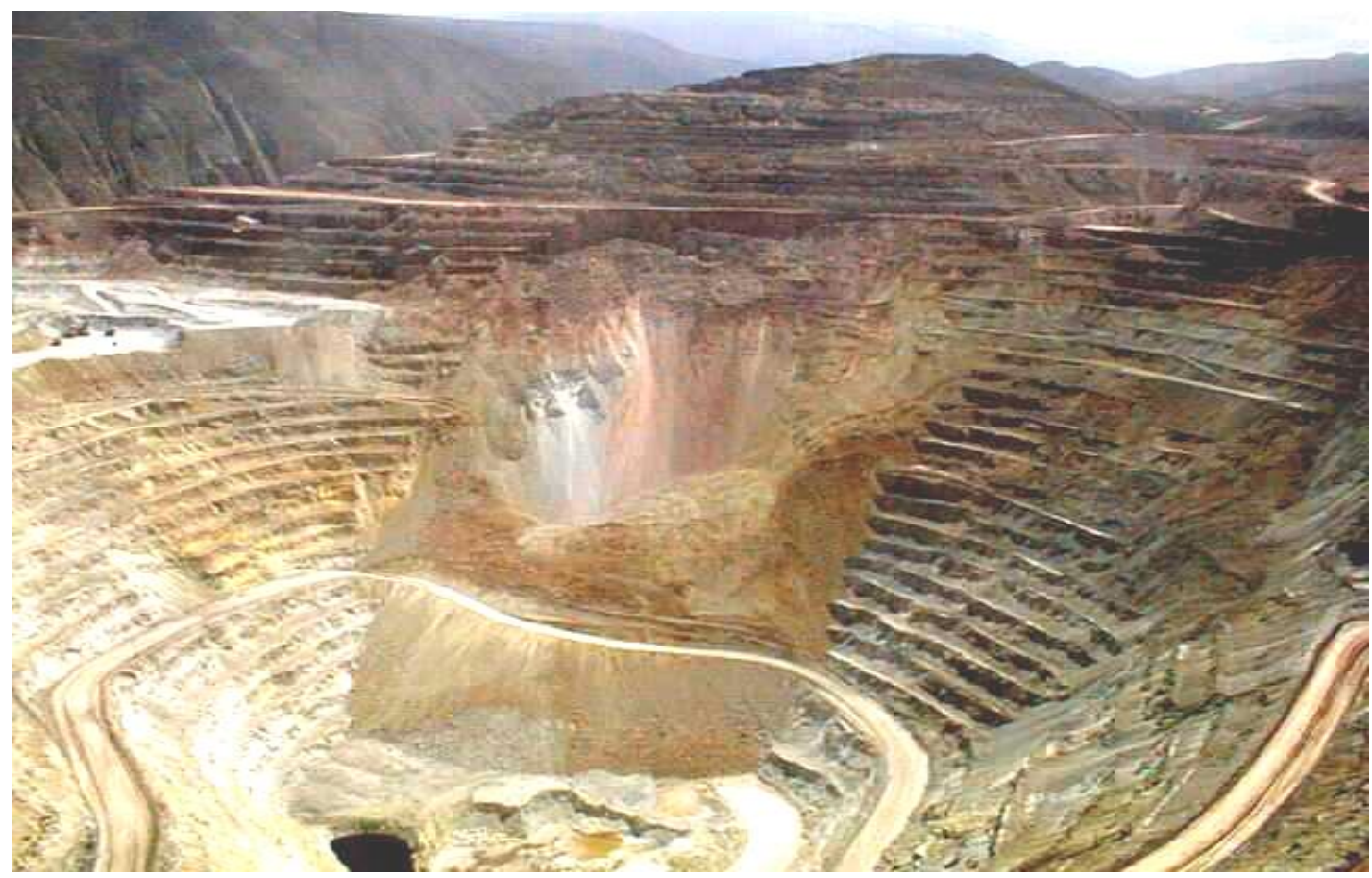

Figure 4 East wall failure (D15) at Cuajone Mine in 1999

\subsection{Acceptability criteria}

The acceptability criteria adopted for the designs are shown in Table 3 . These criteria are based on minimum risk to personnel and equipment, continuous remote monitoring systems, safe double access and exit from the projected pit (Read and Stacey, 2009).

Table 3 Acceptability criteria adopted for Cuajone Mine

\begin{tabular}{ccccc}
\hline \multirow{2}{*}{ Slope Scale } & $\begin{array}{c}\text { Consequence of } \\
\text { Failure }\end{array}$ & FS (min) Static & $\begin{array}{c}\text { Acceptability Criteria } \\
\text { FS (min) Dynamic }\end{array}$ & POF (max) P(FS<1) \\
\hline Bench & Low-high & 1.1 & NA & $25-50 \%$ \\
& Low & $1.15-1.20$ & 1.0 & $25 \%$ \\
Inter-ramp & Medium & 1.20 & 1.0 & $20 \%$ \\
& High & $1.20-1.30$ & 1.1 & $10 \%$ \\
& Low & $1.20-1.30$ & 1.0 & $15-20 \%$ \\
Overall & Medium & 1.30 & 1.05 & $5-10 \%$ \\
& High & $1.30-1.50$ & 1.1 & $<5 \%$ \\
\hline Notes: & & & & \\
FS = Factor of Safety. & & & & \\
POF = Probability of Failure. & & & & \\
\end{tabular}




\subsection{Bench berm design}

Current supergene pit considers a bench height of $15 \mathrm{~m}$. The expected bench face inclination was defined as 65 and $70^{\circ}$ depending on the geotechnical zone. Structurally controlled bench instabilities (i.e. planar failure and wedges) were analysed for all slope orientations and domains. The preliminary analyses were performed using DIPS software (Rocscience Inc., 2005).

Additionally, a verification of the bench berm design with SBLOCK software (Esterhuizen, 2004) was carried out. This software makes use of the Key Block principle (Goodman and Shi, 1985) and joint set statistics to simulate a large number of potential blocks in open pit benches. A calibration on site was carried out using values from the seven structural domains for the different slope orientations. A three-dimensional (3D) plot of the benches indicates the location of failures identified with SBLOCK software (see Figure 5). This output from the program presents a good visual correlation with the observed frequency and type of failure noted in the pit benches. The failure volume and bench widths predicted by the SBLOCK outputs agree sufficiently with the observed instabilities of the slope benches. This initial study validated the adequacy of the methodology and further bench stability will be evaluated using the SBLOCK approach. According to this, the minimum berm width required for the single benches ranges from 6.5 to $8.0 \mathrm{~m}$.

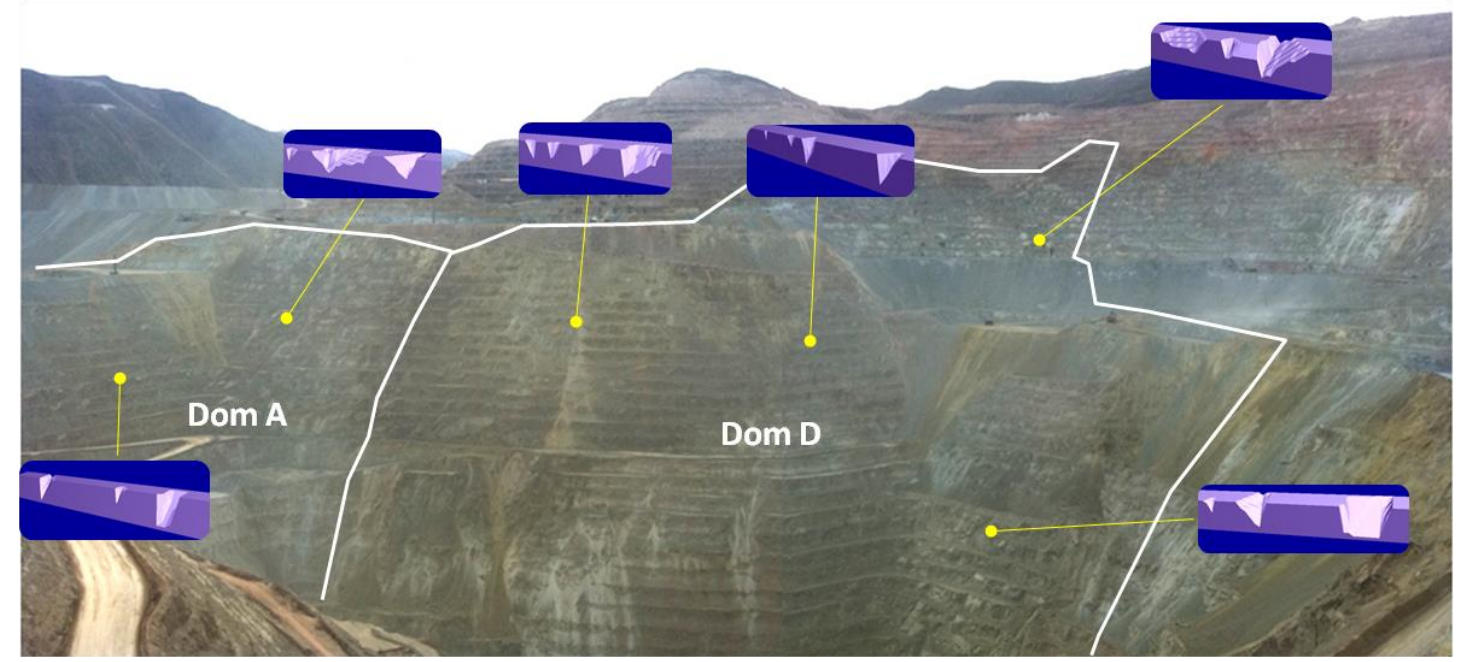

Figure 5 Calibration on site of bench berm analysis. Output of SBLOCK program showing the failed block removed for these slope orientations using structural domain data $A$ and $D$

\subsection{Back-analysis of DSE42 failure}

During 2010, a failure of approximately 5 million tonnes occurred with tension cracks and deformations observed beginning in March). The failure had a very complex mechanism. In the upper part, a planar failure can be observed through a major fault dipping 50 to $53^{\circ}$ (non-daylighting plane). In the central part of the failure, poor rock mass quality (rhyolite argillic) is controlling the deformations. In the lower part, subvertical major faults are present producing toppling style deformations and with good rock mass quality within the LP and BA providing toe support of the above slope. There is also strong evidence that groundwater pressures played a significant role in the failure. Immediately before the failure, there had been a period of heavy rainfall.

In order to perform the back-analysis, a cross section through DSE42 failure was generated and calibration of the slope was performed by finite elements method using Phase ${ }^{2}$ software (Rocscience Inc., 2011). The use of limit equilibrium methods to back-analysed the failure was not considered appropriate in view of the complex failure type. Figure 6 shows calibration of the southeast sector based on total displacements that shows a good correlation with the displacements observed in the pit benches (recorded prisms in the upper part of the failure indicate 15 to $20 \mathrm{~m}$ of displacements). 


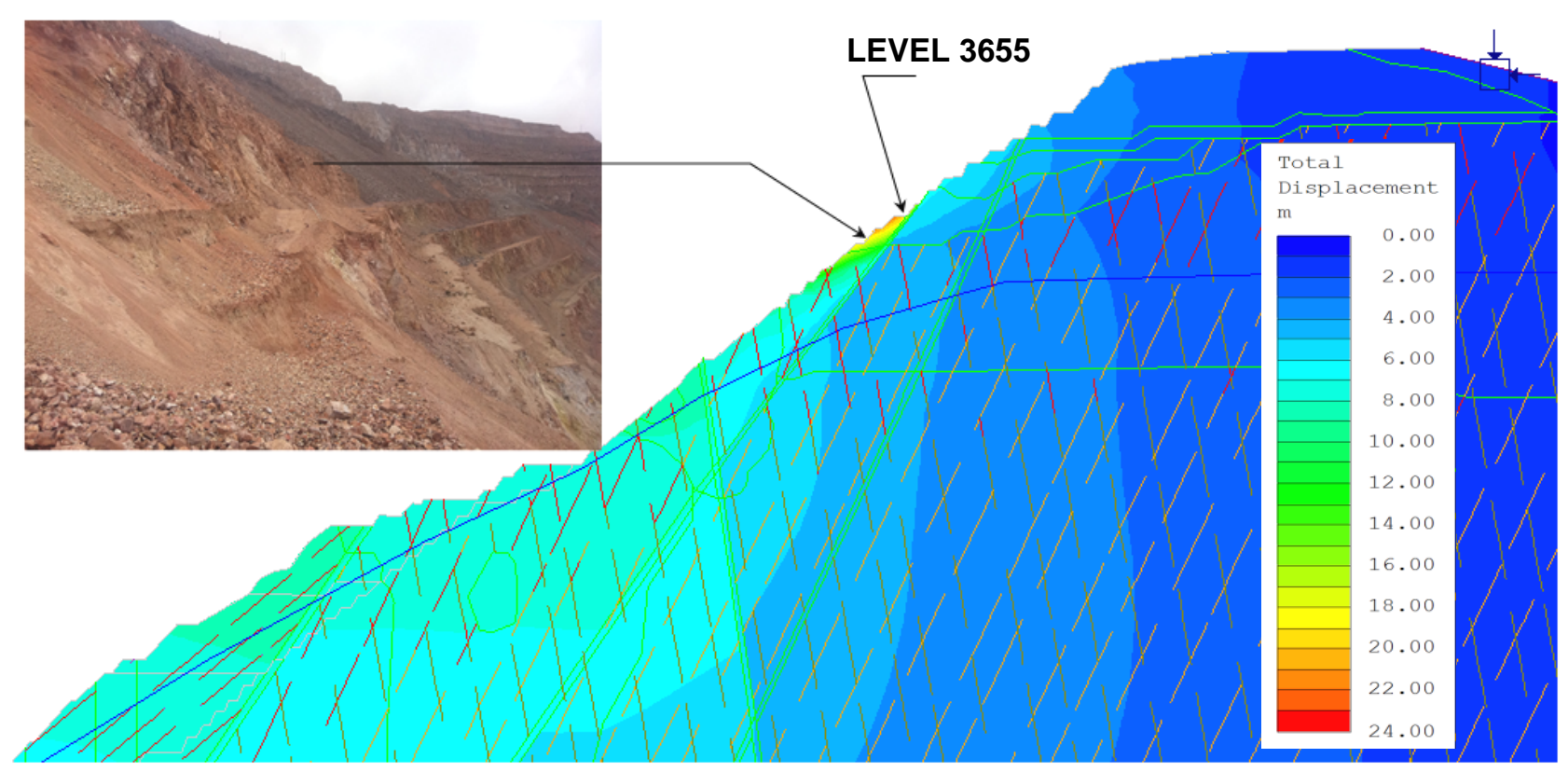

a)

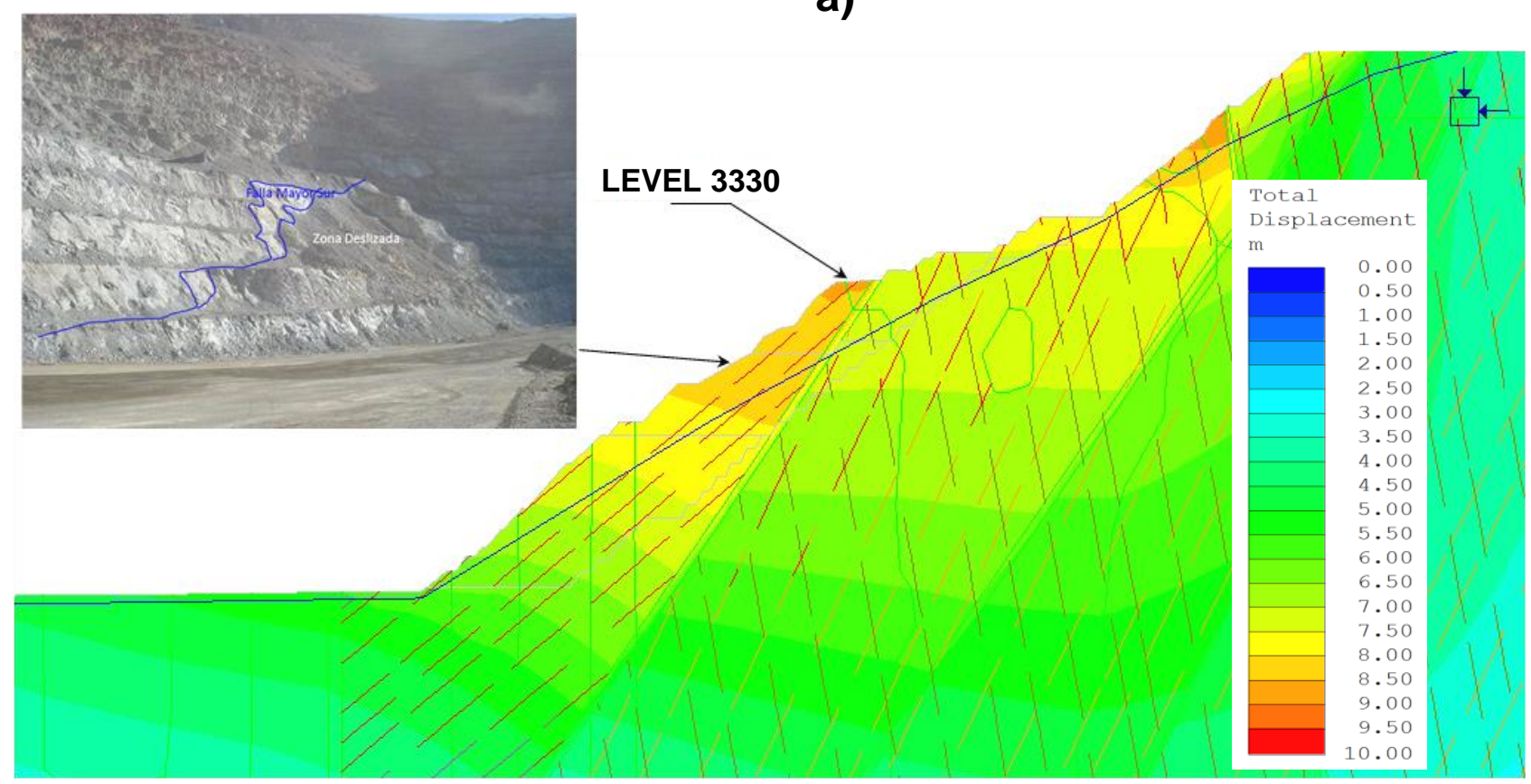

b)

Figure 6 Calibration of southeast sector based on total displacements of back-analysis of DSE42 failure; (a) settlements at level 3655 triggered by poor rock mass quality (Rhyolite Argillic); and (b) displacements at level 3330 triggered by the South major fault

Figure 8(a) presents a sketch generated by the geotechnical team at Cuajone Mine which presented the key aspects of the of DSE42 failure, whilst Figure 7(b) presents the deformed mesh from a back-analysis utilising Phase ${ }^{2}$ program. Comparison of the deformations indicates a very good correlation between failure mechanic observations and the numerical model output. 


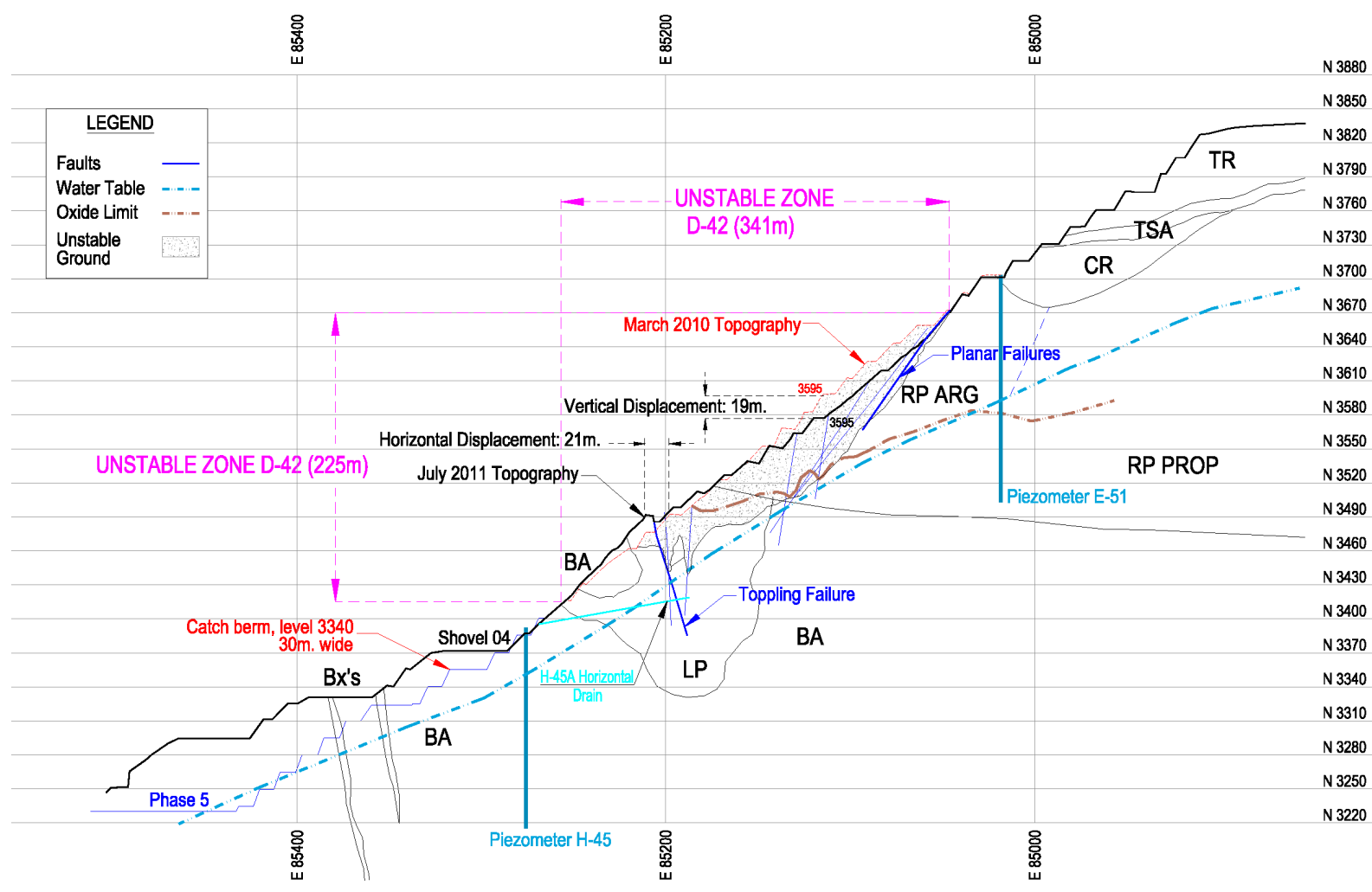

(a)

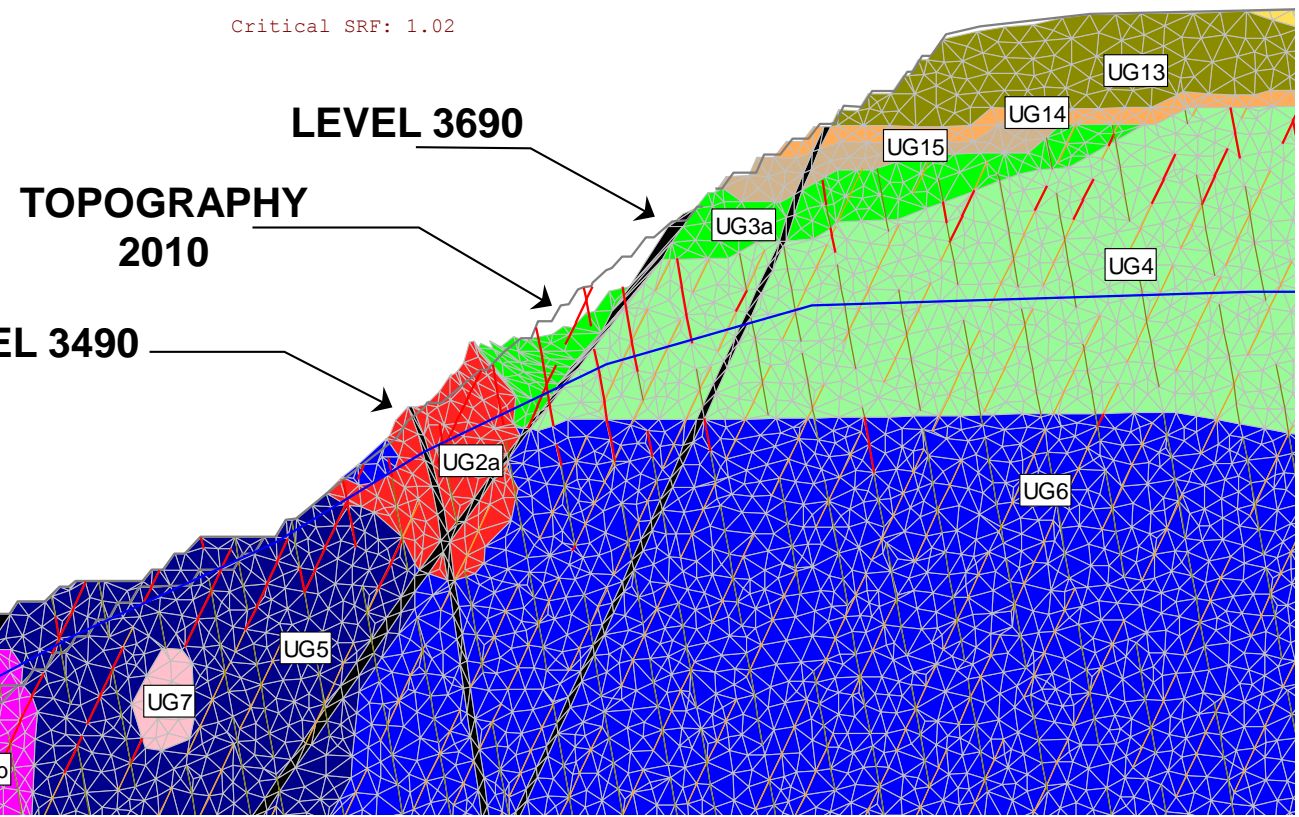

(b)

Figure 7 Back-analysis of DSE42 failure in the southeast sector of the Cuajone pit; (a) Original sketch generated by Cuajone geotechnical team that shows the complex mechanis $m$ of DSE42 failure (Barrios and Veramendi, 2011); and (b) Finite Element analysis of DSE42 failure indicating a FS = 1.02 with shear strength reduction approach and the deformed mesh. Note the good correlation between the deformed shape in (b) with observed movements and displacements in (a); black lines are major faults 


\subsection{Stability analysis}

With the abundance of experience of the different failure modes available at Cuajone Mine, the design of the future planned cutback can be carried out with considerable confidence. Back-analyses play an important part in the confidence of design. This is further backed up by the good data generated following the mapping of structures undertaken since the failures.

For the slope design and analysis of the south wall push back several cross sections were generated. Each section was analysed with the generalised limit equilibrium (GLE) method using Slide software (Rocscience Inc., 2010). The stability analyses were carried out according to the following:

- To include the effect of rock bridges and joint, Jennings (1970) and Prudencio and Van Sint Jan (2007) recommendations were used to define a directional strength. Current pit geometry was analysed in order to calibrate rock mass properties and directional strength.

- In each section all the possible failure combinations were considered: lower and upper inter-ramp, more than one inter-ramp, overall slope and lithological contacts.

- Completely filled tension cracks were used to simulated heavy rain event.

- A path search technique was used to find the most critical failure surface in each case. For the most critical failure surface the probability of failure was computed using the surface response method (Steffen et al., 2008).

- For critical sectors (southeast sector) finite element method using Phase $^{2}$ model was carried out. Shear strength reduction (SSR) technique was used in order to obtain the Factor of Safety (FS). Figure 8 shows the new geotechnical design for the southeast sector including wide catch berms at selective elevations to 'decouple' the slopes.

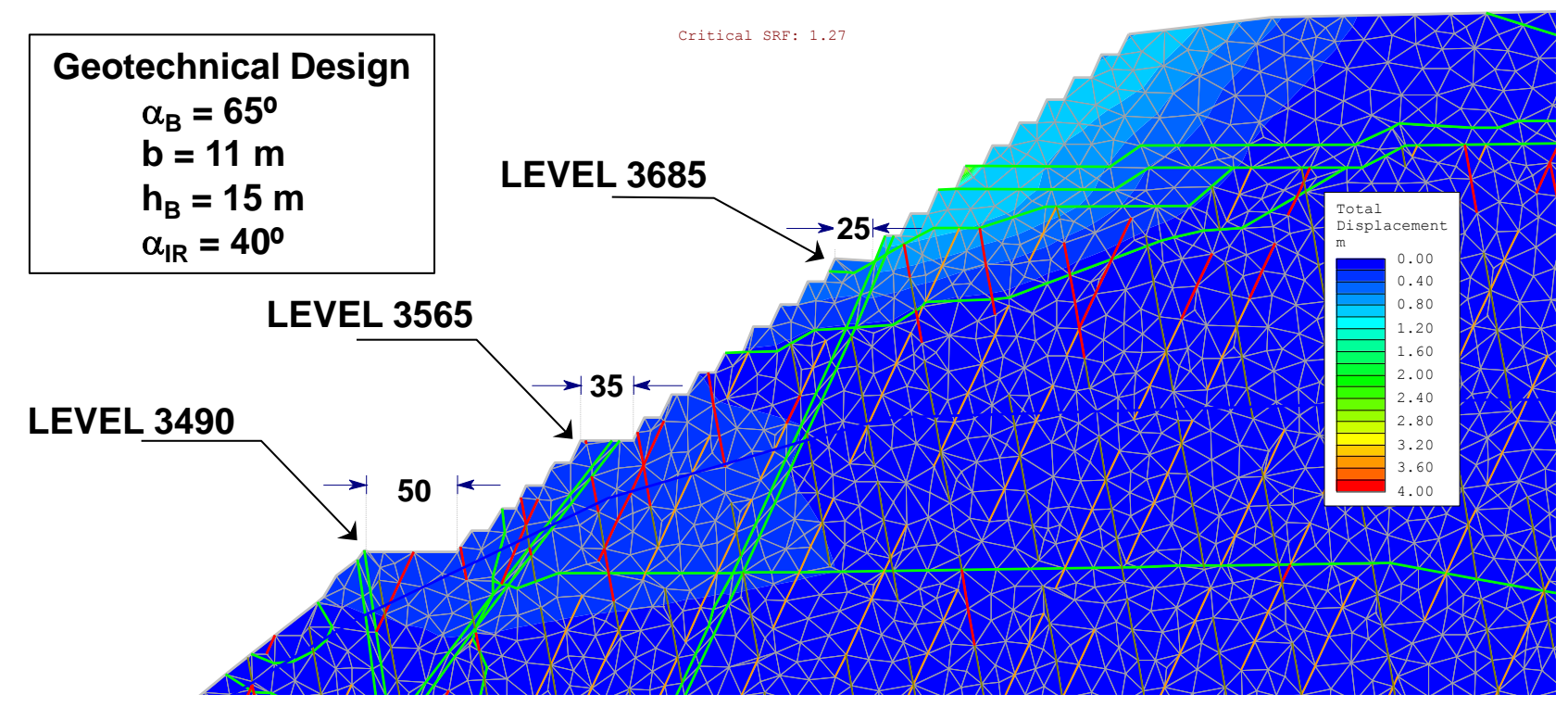

Figure 8 Design for $\mathrm{DSE}_{42}$ for southeast sector of Cuajone pit presenting total displacements. A FS of 1.27 was assessed utilising the SSR approach 


\section{$4 \quad$ Conclusions}

A summary of the field work and analyses for the feasibility stage design has been presented of a pushback at Cuajone. Based on geotechnical and structural characterisation limit equilibrium and numerical methods were used to assess slope stability. The overall slope design is controlled by the stability of the inter-ramp stack, so any optimisation in the overall angle needs to be verified at the inter-ramp level. Also, a new approach is recommended to optimise bench berm design based on key block theory and probabilistic analyses.

The recommended slope design requires good operational and blasting practices, and also efficient slope instrumentation and monitoring system. Currently, the quality of the blast allows well groomed $30 \mathrm{~m}$ double benches, with $70^{\circ}$ bench face inclinations. Pit walls are under continuous monitoring by two robotic Leica APS-Win systems and one radar. Design criteria for the final slopes should be based on the value versus risk trade off, provided that the monitoring system is effective in guaranteeing the safety of personnel (Steffen et al., 2008).

\section{Acknowledgement}

The authors thank and are grateful for the permission and authorisation of Southern Peru Copper Corporation, Peru, and especially the Cuajone mine manager Enrique Paredes to allow us to share mining experience and practice knowledge in this project.

\section{References}

Barrios, J. and Veramendi, R. (2011) Condición Actual Zona Inestable D42, Flanco Oeste (Current condition of failure D42, West Wall), SPCC Internal Report R011, submitted in July.

Bellido, B.E. (1979) Geología del Cuadrángulo de Moquehua (Moquehua Geology): Lima, Perú, Instituto Geológico Minero y Metalúrgico, Perú, boletín 15, 78 p.

Bellido, B.E. and Landa, C. (1965) Mapa geológico del Cuadrángulo de Moquehua 1:100.000 (Geologic map of Moquehua), Lima, Perú, Comisión de la Carta Geológica Nacional.

Bieniawski, Z.T. (1989) Engineering Rock Mass Classifications: A Complete Manual for Engineers and Geologists in Mining, Civil and Petroleum Engineering, J. Wiley \& Sons, Queensland, 272 p.

Esterhuizen, G. (2004) SBLOCK, Vol. 2.01, User Guide and Reference Manual.

Golder Associates, Itasca S.A. and Piteau Associates (2000) Cuajone Pit Slope Design Recommendations, Vol. 1, Technical Report submitted to Southern Peru Copper Corporation, November.

Goodman, R. and Shi, G.H. (1985) Block theory and its application to rock engineering, Prentice Hall, USA.

Hoek, E. (1994) Strength of Rock and Rock Masses, News Journal, International Society for Rock Mechanics, Vol. 2(2), pp. 4-16.

Hoek, E., Carranza, C. and Corkum, B. (2002) Hoek-Brown Failure Criterion 2002 Edition, Mining and Tunnelling Innovation and Opportunity, in Proceedings 5th North American Rock Mechanics Symposium, R. Hammah, W. Bawden, J. Curran and M. Telesnicki (eds), 7-10 August, Ontario, Canada, University of Toronto Press, Toronto, Vol. 1, pp. 267-273.

Hoek, E. and Diederichs, M. (2005) Empirical estimation of rock mass modulus, International Journal of Rock Mechanics and Mining Sciences, Vol. 43(2), pp. 203-215.

Jennings, J.E. (1970) A mathematical theory for the calculation of the stability of slopes in open cast mines, in Proceedings International Symposium Planning Open Pit mines, P.W.J van Rensburg (ed), Johannesburg, A.A. Balkema, Cape Town, pp. 87-102.

Prudencio, M. and Van Sint Jan, M. (2007) Strength and failure modes of rock mass models with non-persistent joints, International Journal of Rock Mechanics and Mining Sciences, Vol. 44, pp. 890-902.

Read, J. and Stacey, P. (2009) Guidelines for Open Pit Slope Design, CRC Press, 1st edition.

Rocscience Inc. (2010) SLIDE v 6.0, Limit Equilibrium Slope Stability Analysis Software, www.rocscience.com.

Rocscience Inc. (2005) DIPS v 5.0, Graphical and statistical Analysis of Orientation Data Software, www.rocscience.com.

Rocscience Inc. (2011) PHASE2 v. 8.0. Finite Element Analysis for Excavations and Slopes Software, www.rocscience.com.

SRK Consulting, Chile (2012) Estudio Geotécnico rajo Cuajone, Technical Report submitted to Southern Peru Copper Corporation, March 2012.

Steffen, O.K.H., Contreras, L.F., Terbrugge, P.J. and Venter, J. (2008) A Risk Evaluation Approach for Pit Slope Design, in Proceedings 42nd US Rock Mechanics Symposium and 2nd US-Canada Rock Mechanics Symposium 2008, 29 June-2 July 2008, San Francisco, America, American Rock Mechanics Association, Virginia, Vol. 2, pp. 833-850.

WMC (1999) Water Management Services. Numerical Models of Groundwater flow in the Toquepala and Cuajone Pit Areas, Technical Report submitted to Southern Peru Copper Corporation, December 1999. 
